\title{
METHODS
}

\section{A Method for Evaluation of the Level of Circulating Mitochondrial DNA by ND1 and ND2 Genes O. B. Ogarkov' ${ }^{1}$ E. A. Orlova ${ }^{1}$, I. V. Malov' ${ }^{2}$ S. N. Zhdanova ${ }^{1}$, S. I. Malov' ${ }^{2}$ P. A. Khromova', L. A. Stepanenko ${ }^{2}$, V. V. Sinkov', L. V. Rychkova ${ }^{1}$, and L. I. Kolesnikova ${ }^{1}$}

Translated from Byulleten' Eksperimental'noi Biologii i Meditsiny, Vol. 172, No. 10, pp. 515-518, October, 2021 Original article submitted June 18, 2021

\begin{abstract}
The measurement of the level of mitochondrial DNA (mtDNA) in the blood is a difficult problem due to high variability of mitochondrial genes, deletions in the mitochondrial genome in some pathological conditions, different sources of mtDNA into the bloodstream (mtDNA from tissues, from blood cells, etc.). We designed primers and TaqMan probes for highly conserved regions of the ND1 and ND2 genes outside the mitochondrial deletions "hot zones". For standardizing the technique, the true concentration of low-molecular-weight mtDNA was determined by real-time PCR for two targets: a fragment of the ND2 gene (122 bp) and the ND1 and ND2 genes (1198 bp). The sensitivity and specificity of the developed approach were verified on a DNA pool isolated from the blood plasma of healthy donors of various nationalities. The concentration of low-molecular-weight mtDNA in the blood plasma of two patients with COVID-19 was monitored over two weeks of inpatient treatment. A significant increase in the content of low-molecular-weight mtDNA was observed during the first 5 days after hospitalization, followed by a drop to the level of healthy donors. The developed technique makes it possible to assess the blood level of low-molecular-weight mtDNA regardless of the quality of sampling and makes it possible to standardize this biological marker in a wide range of infectious and non-infectious pathologies.
\end{abstract}

Key Words: circulating mitochondrial DNA (mtDNA); real-time PCR; COVID-19; NDI and ND2 genes

Mitochondrial DNA (mtDNA) is nucleic acids secreted by damaged or dying cells of parenchymal organs and blood cells. Free circulating mtDNA is included into molecular signals group, this pattern is recognized by type 9 toll-like receptors (TLR9) due to encoded hypomethylated $\mathrm{CpG}$ motifs resembling bacterial motifs [9]. Plasma concentration of mtDNA is increased

\footnotetext{
${ }^{1}$ Research Center for Family Health and Human Reproduction Problems, Irkutsk, Russia; ${ }^{2}$ Irkutsk State Medical University, Ministry of Health of the Russian Federation, Irkutsk, Russia. Address for correspondence: obogarkov@mail.ru. O. B. Ogarkov
}

in patients with acute respiratory syndrome, multiple organ dysfunction during sepsis, trauma, hemorrhagic shock $[2,5,7]$ and a number of other pathological conditions. In patients with COVID-19, high concentrations of mtDNA circulating in the blood are an unfavorable marker associated with the need for patient intubation and a high risk of death [6]. Mitochondrial dysfunction occurs in a wide range of pathologies such as Alzheimer's disease and cancer and during aging. Evaluation of mtDNA content can provide insight into the processes that either initiate or accompany various pathological conditions. For this purpose, the methods 
of reliable assay of the concentration of this biological marker are intensively developed [4]. However, there is a number of problems limiting the ability to assess mtDNA blood level: high variability of mitochondrial genes, deletion of certain parts of the mitochondrial genome in some tissues [4], different sources of circulating mtDNA (tissues and blood cells) [1]. The size of most DNA fragments freely circulating in human blood plasma does not exceed $300 \mathrm{bp}$ [3], and less than $100 \mathrm{bp}$ in the urine [8]. However, the main source of errors in assessing the level of circulating mtDNA in blood plasma most likely are errors at the preanalytical stage associated with improper use of vacuum blood collection systems, the absence of double centrifugation of corpuscles, i.e. "contamination" of low-molecularweight mtDNA pool that has entered the bloodstream from affected organs with fragments of high-molecular-weight mtDNA released from destroyed blood cells. To solve the above problems, primers and TaqMan probes were designed for highly conserved regions of the ND1 and ND2 genes, which are outside the "hot zones" of mitochondrial deletions [4].

The purpose of the study was to standardize the PCR method for determining the concentration of circulating mtDNA calculated as the difference in the content of low-molecular-weight mtDNA (ND2 gene fragment) relative to high-molecular-weight mtDNA (ND1-ND2 genes).

\section{MATERIALS AND METHODS}

The study included 8 healthy donors of different nationalities (self-identification according to personal data): Yakuts (Sakha) (males subjects aged 31 and 47 years), Buryats (a male subject aged 69 years and a female subject aged 50 years), Mongols (a male subject aged 40 years and a female subject aged 29 years), and Russians (female subjects aged 52 and 70 years) and 2 COVID-19 patients (Russians, female subjects aged 62 and 45 years). The blood from the cubital vein collected by a vacuum system with EDTA as anticoagulant was used as the test material in all the cases. To obtain plasma, the blood was centrifuged twice immediately after sampling at $1300 \mathrm{~g}$ for $10 \mathrm{~min}$ at $4{ }^{\circ} \mathrm{C}$ for sedimentation of blood cells. The plasma was repeatedly centrifuged in $1.5-\mathrm{ml}$ plastic vials at $14,000 \mathrm{~g}$ for $5 \mathrm{~min}$ at room temperature. The supernatant was transferred to clean vials, aliquoted, and stored at $-80^{\circ} \mathrm{C}$. DNA was extracted from $100 \mu \mathrm{l}$ using DNeasy Blood Tissue Kits (Qiagen). Real-time PCR with primers (Eurogen) and TaqMan probes (Synthol) or SYBR Green qPCR Ready Mix (Sigma) solution was conducted for 45 cycles using AmpliTaq Gold 360 Master Mix reagents (Applied Biosystems) in the presence of $1 \times$ enhancer solution from the same kit on a CFX-96 cycler (Bio-Rad). Amplification protocol for low-molecular-weight mtDNA: $10 \mathrm{~min}$ at $95^{\circ} \mathrm{C}$, polymerase activation; $15 \mathrm{sec}$ at $95^{\circ} \mathrm{C} ; 15 \mathrm{sec}$ at $58^{\circ} \mathrm{C}$; $15 \mathrm{sec}$ at $72^{\circ} \mathrm{C}$; for high-molecular-weight mtDNA: $10 \mathrm{~min}$ at $95^{\circ} \mathrm{C}$, polymerase activation; $60 \mathrm{sec}$ at $95^{\circ} \mathrm{C}$; $15 \mathrm{sec}$ at $57^{\circ} \mathrm{C} ; 70 \mathrm{sec}$ at $72^{\circ} \mathrm{C}$.

Primers and probes (Table 1) were selected manually considering the variability data from human reference mitochondrial genome NC_012920.1 and the MITOMAP database (https://www.mitomap.org/MITOMAP).

Statistical processing of the results was performed using the Microsoft Excel 7.0 spreadsheet processor

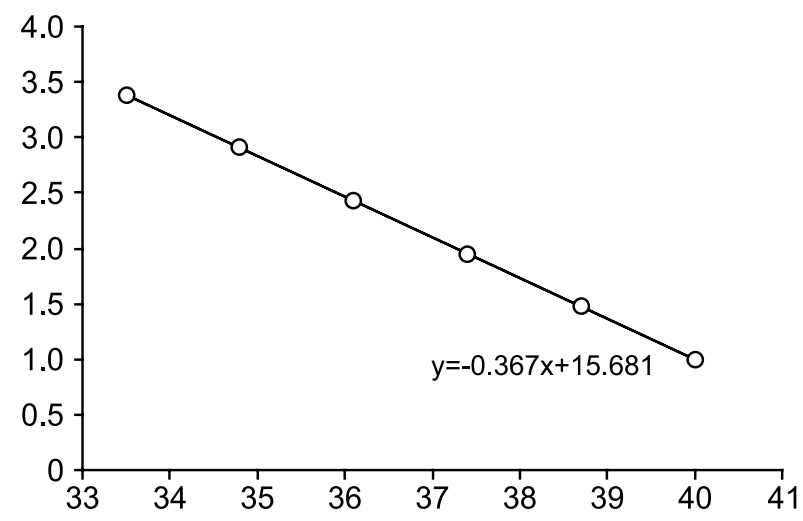

Fig. 1. Calibration curve. Ordinate: decimal logarithm of mtDNA concentration in genome equivalents in the samples obtained by successive 3-fold dilutions. Abscissa: threshold cycle Ct.

TABLE 1. Primers and Probes Used in the Study

\begin{tabular}{l|r|c|c}
\hline \multicolumn{1}{c|}{$\begin{array}{c}\text { Primers/ } \\
\text { Probes }\end{array}$} & Sequence 5' $\rightarrow 3{ }^{\prime}$ & Length, bp & Annealing, ${ }^{\circ} \mathrm{C}$ \\
\hline Mt4463 F & CGTACTAATTAATCCCCTGGC (F) & 122 & 58 \\
Mt4585R & GCTAGCATGTTTATTTCTAGGC (R) & \\
Mt3440 & [FAM]-GCGTCAGCGAAGGGTTGTAG[T-LNA]AG-[BHQ1] & 1198 & 57 \\
Mt3387 F & AAATTCTAGGCTATATACAACTAC (F) & \\
Mt4585R & GCTAGCATGTTTATTTCTAGGC* (R) & \\
\hline
\end{tabular}

Note. ${ }^{*}$ PCR visualization SYBR Green qPCR Ready Mix (Sigma). 


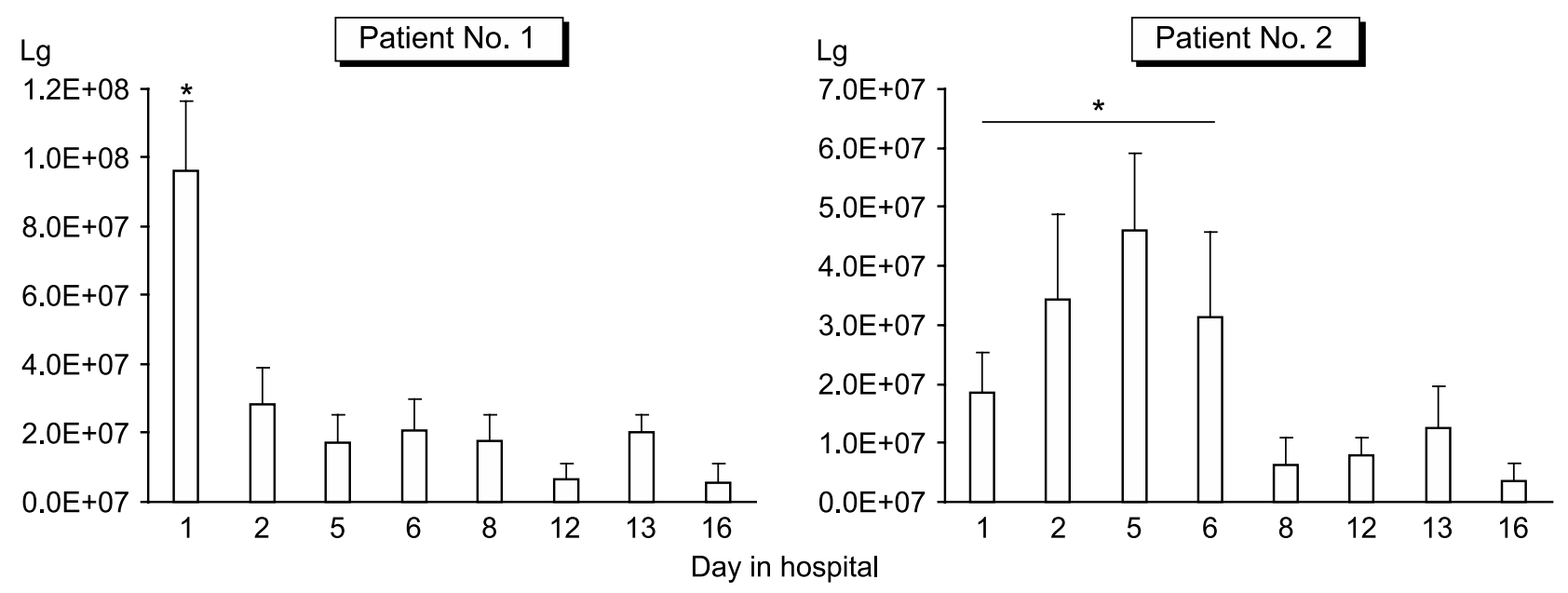

Fig. 2. Standardized content of mtDNA in the plasma of two COVID-19 patients. ${ }^{*} p \leq 0.05$ in comparison with subsequent days.

and Statistica 6.0 software (StatSoft, Inc.). The significance of difference between the values was estimated by ANOVA and Mann-Whitney $U$ test. The difference was considered statistically significant at $p \leq 0.05$.

\section{RESULTS}

The calibration curve was constructed for pooled DNA sample from healthy donors of different nationalities (Fig. 1). The $\mathrm{Ct}$ value equal to 40 cycles was taken as 10 genome equivalents in the sample. The empirical equation $y=-0.367 x+15.681$ was used for further calculations of mtDNA concentration per $1 \mathrm{ml}$ plasma.

To check the specificity of the developed tests, PCR tests were performed in triplicates with each of the 8 samples from subjects of different nationalities to assess the content of high- and low-molecular-weight mtDNA. The normalized value was calculated using the empirical formula (Fig. 1) per $1 \mathrm{ml}$ plasma. True value of circulating low-molecular-weight mtDNA was calculated in genome equivalents as the difference between the concentration of low-molecularweight mtDNA and high-molecular-weight mtDNA. The mean value equal to $5.6 \times 10^{6}$ genome equivalents of mtDNA per $1 \mathrm{ml}$ donor plasma was obtained. However, in many test samples, high-molecular-weight mtDNA contamination exceeded $5 \%$, i.e. was more than $2.8 \times 10^{5}$. In other words, even the observance of all conditions at the preanalytical stage do not guarantee the presence of significant amounts of high-molecular-weight mtDNA extracted from blood cells during hemolysis, platelet lysis, etc.

A significant decrease in mtDNA concentration on day 2 (Patient No. 1) and on days 5-6 of treatment (Patient No. 2) was demonstrated. (Fig. 2). A common trend is observed; the difference in treatment days between the patients is probably determined by the delay in patient No. 2 hospitalization.
Thus, we have developed a real-time PCR-based molecular biological approach, which allows the use of circulating mtDNA level as a biological marker in healthy and infected people.

The authors declare no conflict of interest.

The study was conducted as part of research project AAAA-A18-118012990006-7 "Search for new biomarkers for early diagnosing and prediction of the outcomes of socially important infectious diseases".

\section{REFERENCES}

1. Al Amir Dache Z, Otandault A, Tanos R, Pastor B, Meddeb R, Sanchez C, Arena G, Lasorsa L, Bennett A, Grange T, El Messaoudi S, Mazard T, Prevostel C, Thierry AR. Blood contains circulating cell-free respiratory competent mitochondria. FASEB J. 2020;34(3):3616-3630. doi: 10.1096/ fj.201901917RR

2. Faust HE, Reilly JP, Anderson BJ, Ittner CAG, Forker CM, Zhang P, Weaver BA, Holena DN, Lanken PN, Christie JD, Meyer NJ, Mangalmurti NS, Shashaty MGS. Plasma Mitochondrial DNA Levels Are Associated With ARDS in Trauma and Sepsis Patients. Chest. 2020;157(1):67-76. doi: 10.1016/j. chest.2019.09.028

3. Li Y, Zimmermann B, Rusterholz C, Kang A, Holzgreve W, Hahn S. Size separation of circulatory DNA in maternal plasma permits ready detection of fetal DNA polymorphisms. Clin. Chem. 2004;50(6):1002-1011. doi: 10.1373/ clinchem.2003.029835

4. Phillips NR, Sprouse ML, Roby RK. Simultaneous quantification of mitochondrial DNA copy number and deletion ratio: a multiplex real-time PCR assay. Sci. Rep. 2014;4:3887. doi: 10.1038/srep03887

5. Puskarich MA, Shapiro NI, Trzeciak S, Kline JA, Jones AE. Plasma levels of mitochondrial DNA in patients presenting to the emergency department with sepsis. Shock. 2012;38(4):337340. doi: 10.1097/SHK.0b013e318266a169

6. Scozzi D, Cano M, Ma L, Zhou D, Zhu JH, O'Halloran JA, Goss C, Rauseo AM, Liu Z, Sahu SK, Peritore V, Rocco M, Ricci A, Amodeo R, Aimati L, Ibrahim M, Hachem R, Krei- 
sel D, Mudd PA, Kulkarni HS, Gelman AE. Circulating mitochondrial DNA is an early indicator of severe illness and mortality from COVID-19. JCI Insight. 2021;6(4):e143299. doi: $10.1172 /$ jci.insight. 143299

7. Simmons JD, Lee YL, Mulekar S, Kuck JL, Brevard SB, Gonzalez RP, Gillespie MN, Richards WO. Elevated levels of plasma mitochondrial DNA DAMPs are linked to clinical outcome in severely injured human subjects. Ann. Surg. 2013;258(4):591-596; discussion 596-598. doi: 10.1097/ SLA.0b013e3182a4ea46
8. Sinkov VV, Ogarkov OB, Plotnikov AO, Gogoleva NE, Zhdanova SN, Pervanchuk VL, Belkova NL, Koshcheev ME, Thomas TA, Liu J, Zorkaltseva EY, Heysell SK. Metagenomic analysis of mycobacterial transrenal DNA in patients with HIV and tuberculosis coinfection. Infect. Genet. Evol. 2020;77:104057. doi: 10.1016/j.meegid.2019.104057

9. Zhang Q, Raoof M, Chen Y, Sumi Y, Sursal T, Junger W, Brohi K, Itagaki K, Hauser CJ. Circulating mitochondrial DAMPs cause inflammatory responses to injury. Nature. 2010;464:104107. doi: $10.1038 /$ nature 08780 